\title{
A RELIABLE APPROACH TO A RAPID CALCULATION OF THE GRAIN SIZE OF POLYCRYSTALLINE THIN FILMS AFTER EXCIMER LASER CRYSTALLIZATION
}

\author{
ZANESLJIV NAČIN HITREGA IZRAČUNA VELIKOSTI ZRN V \\ POLIKRISTALNI TANKI PLASTI PO UV-LASERSKI \\ KRISTALIZACIJI
}

\author{
Chil-Chyuan Kuo \\ Department of Mechanical Engineering, Ming Chi University of Technology, No. 84, Gungjuan Road, Taishan Taipei Hsien 243, Taiwan \\ jacksonk@mail.mcut.edu.tw \\ Prejem rokopisa - received: 2013-10-08; sprejem za objavo - accepted for publication: 2014-11-27
}

doi:10.17222/mit.2013.237

\begin{abstract}
Excimer laser crystallization (ELC) is the most commonly employed technology for fabricating low-temperature polycrystalline silicon (LTPS) thin films. The grain size of polycrystalline thin films after ELC is usually determined with a manual calculation, which includes certain disadvantages, i.e., human error and is time-consuming and exhausting. To mitigate these disadvantages, a high-efficiency approach to calculating the grain size of polycrystalline thin films automatically is proposed. It was found that the selected-boundary-definition approach is a promising candidate for calculating the grain size of polycrystalline thin films. The savings in the analysis time is up to $75 \%$. The average error rate of the measurement can be controlled within $8.33 \%$. Keywords: low-temperature polycrystalline silicon, automatic grain-size analysis, excimer laser crystallization
\end{abstract}

UV-laserska kristalizacija (ELC) je najbolj pogosto uporabljena tehnologija za izdelavo nizkotemperaturne polikristalne tanke plasti silicija (LTPS). Velikost zrn v polikristalni tanki plasti po ELC se navadno določa z ročnim izračunom, ki pa ima nekatere pomanjkljivosti, kot je človeška napaka, in je časovno potratna in utrujajoča. Za ublažitev teh pomanjkljivosti je predlagan zelo učinkovit, avtomatičen način za izračun velikosti zrn v polikristalni tanki plasti. Ugotovljeno je, da je približek k selektivnemu določanju meje obetajoč način za izračun velikosti zrn polikristalnih tankih plasti. Prihranek časa za analizo je do $75 \%$. Povprečni odmik napake pri meritvah je okrog $8,33 \%$.

Ključne besede: nizkotemperaturni polikristalni silicij, avtomatska analiza velikosti zrn, UV-laserska kristalizacija

\section{INTRODUCTION}

High-performance complementary metal-oxide-semiconductor (CMOS) circuits on glass are essential for the system-on panel (SOP) technology, which has potential applications in various information devices including cell-phones, laptop computers and large-size flat panel television sets. Polycrystalline silicon (poly-Si) thin films have been widely used as CMOS gates, thin-film transistors (TFTs), solar cells and various other applications in semiconductor-device technology. Excimer laser crystallization (ELC) is an industrial technique used for preparing poly-Si thin films on commercially available, inexpensive glass substrates for the development of high-performance TFTs in active-matrix flat panel displays. ${ }^{1-6}$ A rapid deposition of the laser-energy density, on a nanosecond time scale, onto the surface region of the an amorphous-silicon ( $\mathrm{a}-\mathrm{Si}$ ) thin film leads to its melting and recrystallisation into a poly-Si thin film, while keeping the glass substrate at a low temperature. The final quality of the device depends significantly on the phase-transformation mechanisms which need to be manipulated precisely for obtaining poly-Si thin films with a large grain size and a good uniformity. The phase-transformation mechanisms of a-Si thin films have been extensively investigated using an in-situ optical diagnostic technique during ELC in the previous stur dies. ${ }^{7-17}$ Numerous researches have been done for fabricating large-grained poly-Si thin films because the performance of TFTs is significantly affected by the size of the poly-Si thin films after ELC. ${ }^{18-23}$ Until now, however, the grain size of the poly-Si thin films after ELC has usually been determined with a manual calculation. This approach included certain disadvantages such as human error and was time-consuming and exhausting. Therefore, a high-efficiency approach is proposed in this work for calculating the grain size of polycrystalline thin films efficiently and accurately using the Image-Pro software. ${ }^{24,25}$

\section{EXPERIMENT}

Figure 1 shows a schematic illustration of the experimental set-up for ELC. The sample has a stacked structure consisting of a thick $300 \mathrm{~nm} \mathrm{SiO}_{2}$ capping layer and a thick $90 \mathrm{~nm}$ a-Si layer formed on a thick $0.7 \mathrm{~mm}$ non-alkali glass substrate (Corning 1737). All the films were prepared with plasma-enhanced chemical vapor deposition (PECVD). These samples were then dehydroge- 


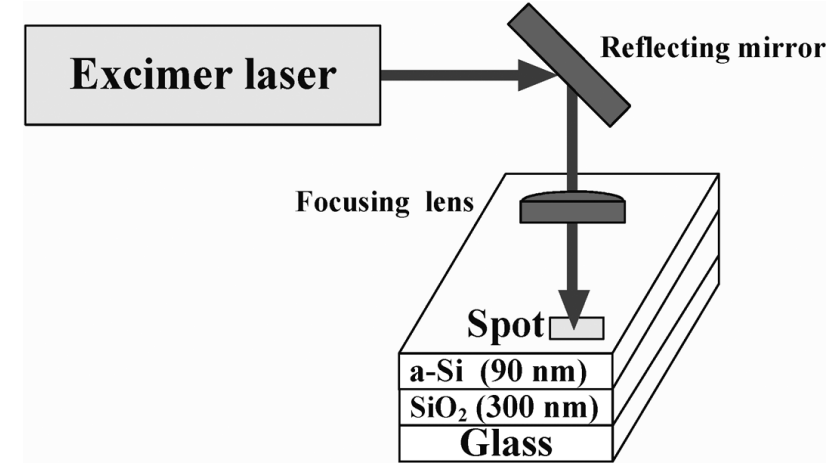

Figure 1: Schematic illustration of the experimental set-up for ELC Slika 1: Shematski prikaz eksperimentalnega sestava za ELC

nated with a thermal treatment at $500{ }^{\circ} \mathrm{C}$ for $2 \mathrm{~h}$ to reduce the hydrogen content in order to prevent the ablation caused by a sudden hydrogen eruption during ELC. ${ }^{26}$ The samples were then held by self-closing tweezers at the end of a cantilever beam fixed to an $x-y$ precision translation stage. The $x$ - and $y$-axis displacements of the two stages can be accurately manipulated (resolution $=0.625 \mu \mathrm{m}$ ). The movement of the focusing lens mounted onto a $z$-axis stage was precisely controlled to adjust the desired excimer laser fluences for crystallization. The pulsed excimer laser-energy levels were monitored using a laser power meter (Vector H410 SCIENTECH). The variation in the pulse-to-pulse excimer laser energy was found to be less than $5 \%$. The a-Si thin films were irradiated with an excimer laser beam $(\lambda=351 \mathrm{~nm}$, repetition rate $=1 \mathrm{~Hz}$, LAMBDA PHYSIK COMPex 102) with laser fluences ranging from $100 \mathrm{~mJ} / \mathrm{cm}^{2}$ to $500 \mathrm{~mJ} / \mathrm{cm}^{2}$. A stainless-steel slit $(2 \mathrm{~mm} \times$ $15 \mathrm{~mm}$ ) located in the optical path of the excimer laser was employed to transform the incident Gaussian beam into a rectangular beam spot with a better than $\pm 10 \%$ energy variation. All the experiments were performed at ambient temperature and pressure.

After ELC, the microstructural analyses of the annealed poly-Si thin films were carried out using field emission scanning electron microscopy (FE-SEM) with

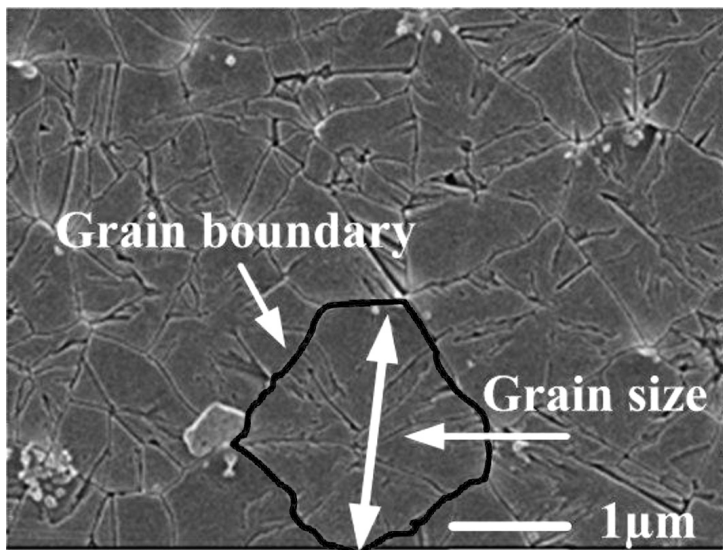

Figure 2: SEM micrograph of poly-Si thin films after ELC Slika 2: SEM-posnetek poli-Si tanke plasti po ELC
JEOL JSM-6500F. Before the FE-SEM observation, the crystallized silicon films were Secco-etched in order to highlight the grain boundaries (GBs) and intra-grain defects. ${ }^{27}$ The acceleration electron beam energy for FE-SEM was $15 \mathrm{kV}$ (a resolution of $1.5 \mathrm{~nm}$ ). Six approaches (count, auto-split, watershed split, limited watershed split, boundary definition and selected-boundary definition) were employed for calculating the grain size of the poly-Si thin films.

\section{RESULTS AND DISCUSSION}

Figure 2 shows a typical SEM micrograph of the poly-Si thin films after ELC. The grain size can be determined from the longest length inside the grain boundary. To determine the best approach to replace the tradition manual-calculation method, a test SEM micrograph was selected to be investigated. Figure 3 shows the grain-size calculation result using the manual-calculation approach. The total number of the grain size of poly-Si was 24 . The largest grain size, the smallest grain size and the average grain size were $(333.3,26.6$ and 152.2) $\mathrm{mm}$, respectively. Figure 4 shows the grain-size calculation result using six different approaches. Figure 5 shows the variation in the counts of the grain size for seven different calculation approaches. The average error rate for the approaches of count, auto-split, watershed split, limited watershed split, boundary definition and selected-boundary definition was $(21.32,19.33,20.76$, 20.76, 16.29 and 8.33) \%, respectively. As one can see, the selected-boundary-definition approach provides the lowest average error rate in the grain-size calculation compared with the tradition manual-calculation approach in this case. The average error rates for the approaches of count, auto-split, watershed split and limited watershed split were higher than those of the approaches of boundary definition and selected-boundary definition because the Image-Pro software cannot precisely evaluate the

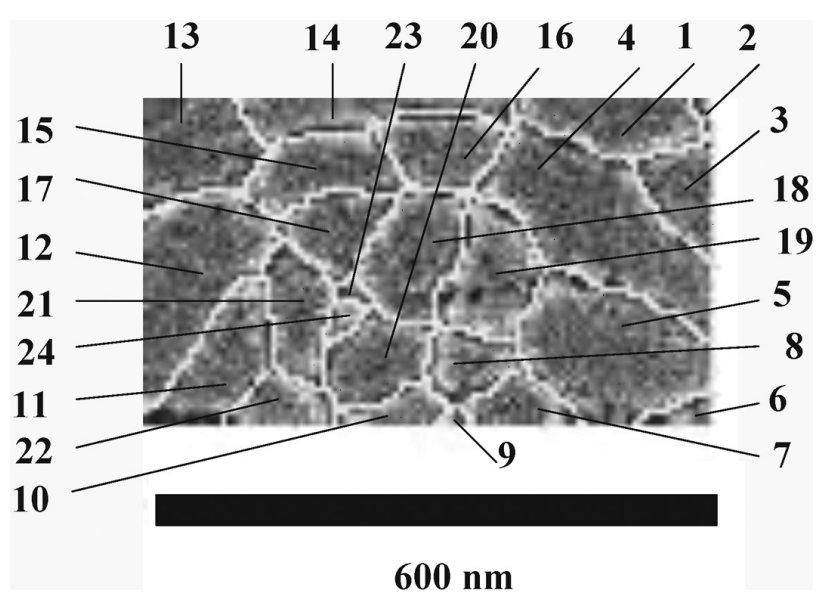

Figure 3: Grain-size calculation result using manual-calculation approach

Slika 3: Izračun velikosti zrn z ročnim štetjem 


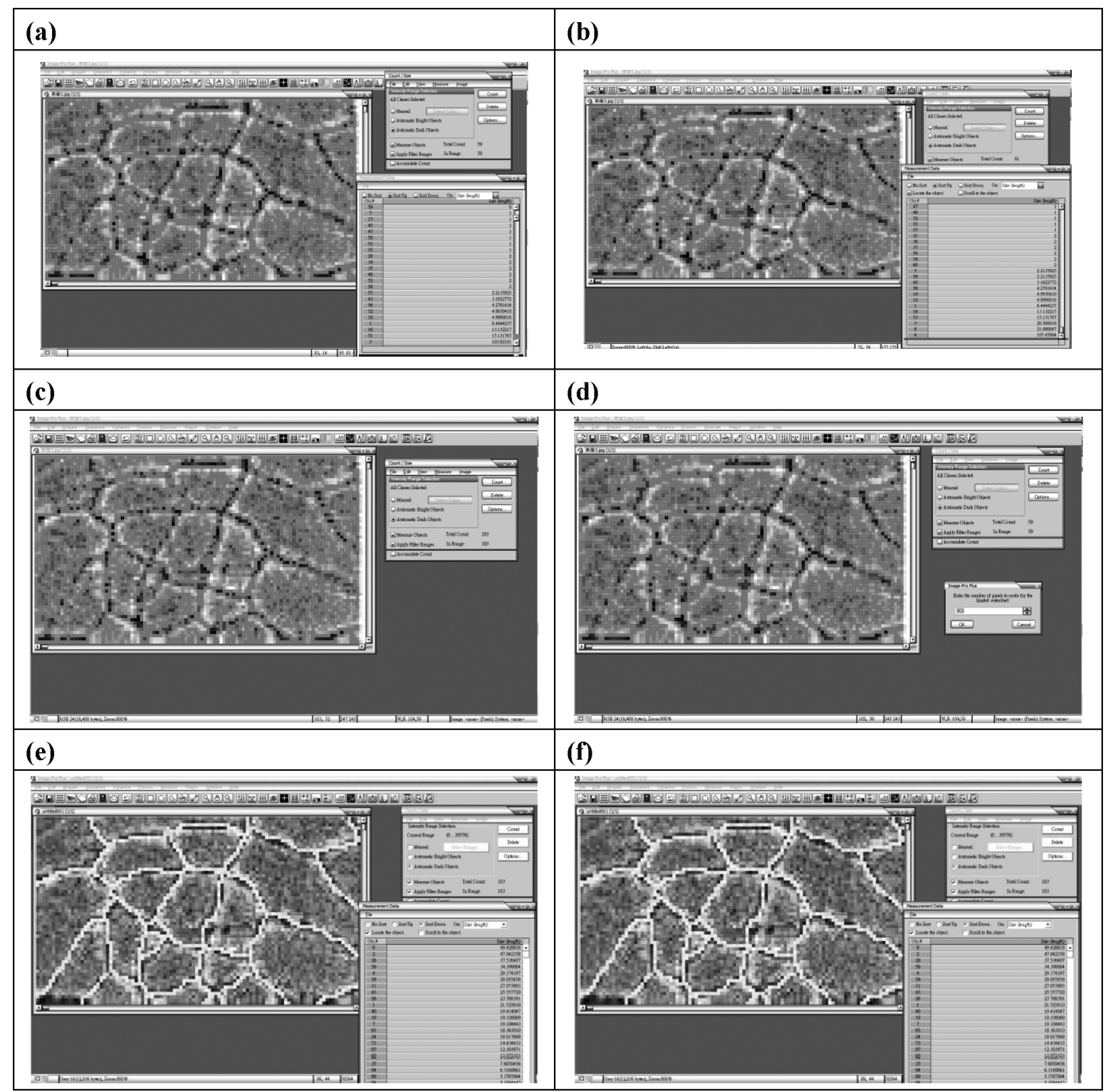

Figure 4: Grain-size calculation result using six different approaches of: a) count, b) auto-split, c) watershed split, d) limited watershed split, e) boundary definition and f) selected-boundary definition

Slika 4: Rezultat izračuna velikosti zrn s šestimi različnimi načini: a) štetje, b) avtomatska razdelitev, c) razdelitev po razvodnicah, d) omejena razdelitev po razvodnicah, e) definicija mej in f) selektivna definicija mej

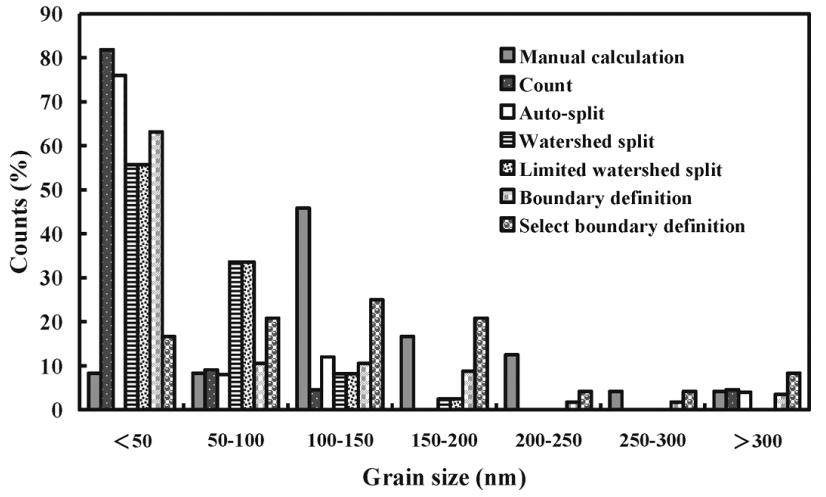

Figure 5: Variation in the counts of the grain size for seven different calculation approaches

Slika 5: Razlike v izračunu velikosti zrn pri sedmih različnih načinih izračuna

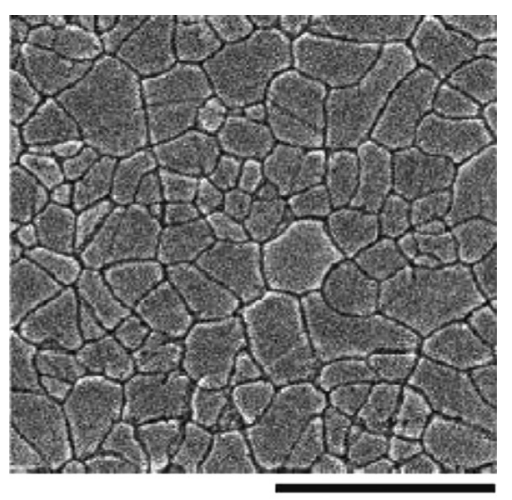

$600 \mathrm{~nm}$

Figure 6: SEM micrograph of poly-Si thin film of case study $1^{28}$

Slika 6: SEM-posnetek poli-Si tanke plasti pri študiju primera $1^{28}$ 


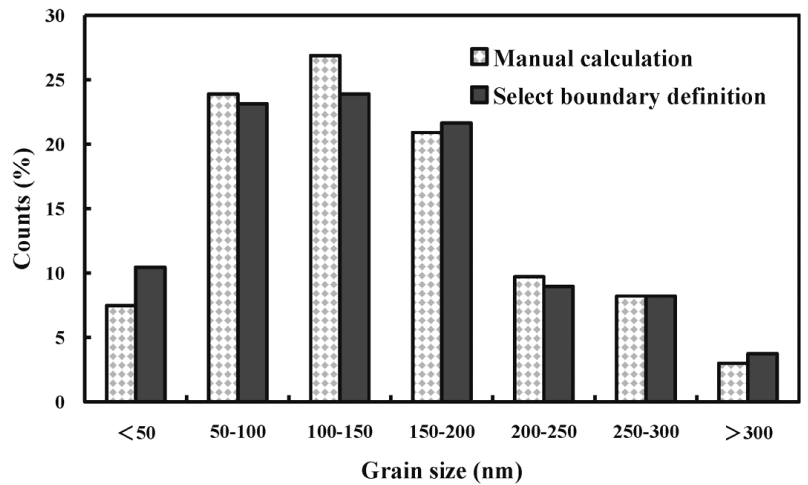

Figure 7: Variation in the counts of the grain size for two different calculation approaches in case study 1

Slika 7: Razlike v izračunu velikosti zrn pri dveh različnih načinih izračuna za primer 1

grain boundary of a SEM micrograph. To reduce the average error rate of the measurement, the two approaches of boundary definition and selected-boundary definition were further applied. The average error rate of the measurement was still not acceptable, though the boundary-definition approach can reduce the average error rate of the measurement. Finally, the selectedboundary-definition approach was applied. The selected-boundary-definition approach provides the best accuracy of the grain-size calculation because the grain boundary of the SEM micrograph was traced first and then calculated using the Image-Pro software.

To evaluate the accuracy of the selected-boundarydefinition approach, two case studies were applied to investigate the average error rate. Figure 6 shows a SEM micrograph of the poly-Si thin film of case study $1 .{ }^{28}$ Figure 7 shows the variation in the counts of the grain size for two different calculation approaches in case study 1 . The average error rate of the measurement was only $1.28 \%$. In this case, the total time for calculating the grain size with the manual calculation was approximately $16 \mathrm{~h}$. However, the total calculating time was drastically reduced to approximately $4 \mathrm{~h}$ using the

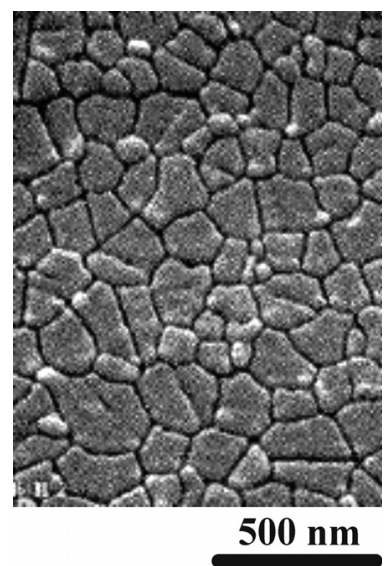

Figure 8: SEM micrograph of poly-Si thin film of case study $22^{28}$ Slika 8: SEM-posnetek poli-Si tankih plasti pri študiju primera $2{ }^{28}$

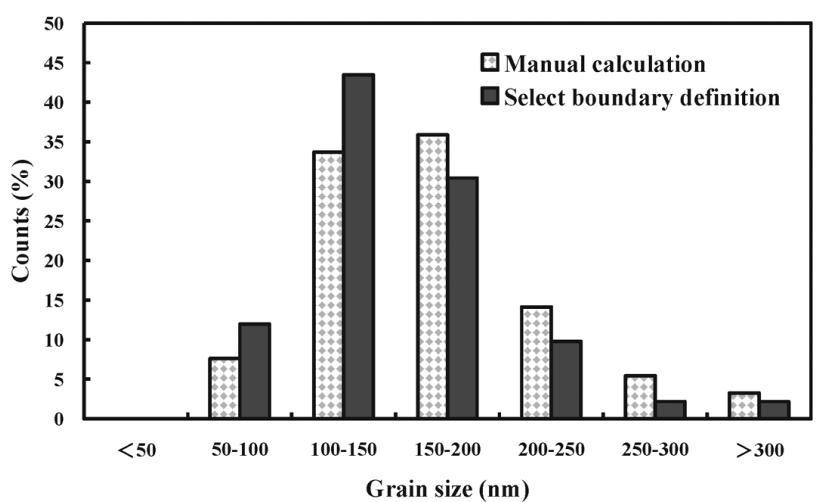

Figure 9: Variation in the counts of the grain size for two different calculation approaches in case study 2

Slika 9: Razlike v izračunu velikosti zrn pri dveh različnih načinih izračuna, za primer 2

selected-boundary-definition approach. The saving in the analysis time was up to $75 \%$. Figure 8 shows a SEM micrograph of the poly-Si thin film of case study 2 . Figure 9 shows the variation in the counts of the grain size for two different calculation approaches in case study $2 .{ }^{28}$ The average error rate of the measurement was only $4.03 \%$. In this case, the total time for calculating the grain size with the manual calculation was approximately $12 \mathrm{~h}$. However, the total calculating time was drastically reduced to approximately $3 \mathrm{~h}$ using the selected-boundary-definition approach. The saving in the analysis time was up to $75 \%$. It is worth noting that the average error rate of the measurement was obviously smaller than for the test sample because the grain boundary was clear for the two SEM micrographs. Thus, a SEM micrograph with a clear grain boundary is critical for calculating the grain size with the Image-Pro software when the Secco etching is employed ${ }^{29-31}$.

As discussed above, the Image-Pro software is a powerful tool for analyzing the grain size of the poly-Si thin films after ELC. The saving in the analysis time is up to $75 \%$ and the average error rate of the measurement can be controlled within $8.33 \%$ when using the computer-calculation approach compared with the manual-calculation approach.

\section{CONCLUSIONS}

A simple and highly efficient approach for calculating the grain size of the poly-Si thin films after ELC was successfully demonstrated. A SEM micrograph with a clear grain boundary is critical for calculating the grain size with the Image-Pro software. The selected-boundary-definition approach was proved to be a promising candidate for calculating the grain size of the poly-Si thin films efficiently and accurately. The saving in the analysis time was up to $75 \%$ and the average error rate of the measurement can be controlled within $8.33 \%$ when compared with the manual-calculation approach. 


\section{Acknowledgements}

This work was financially supported by the National Science Council of Taiwan under contract nos. NSC 102-2221-E-131-012 and NSC 101-221-E-131-007. The skillful technical assistance of Mr. Kun-Wei Wu of the Ming Chi University of Technology is gratefully acknowledged.

\section{REFERENCES}

${ }^{1}$ J. S. Im, R. S. Sposili, M. A. Crowder, Single-crystal Si films for thin-film transistor devices, Applied Physics Letters, 70 (1997) 19, 3434-3436, doi:10.1063/1.119194

${ }^{2}$ L. Mariucci, R. Carluccio, A. Pecora, V. Foglietti, G. Fortunato, P. Legagneux, D. Pribat, D. Della Sala, J. Stoemenos, Lateral growth control in excimer laser crystallized polysilicon, Thin Solid Films, 337 (1999) 1-2, 137-142, doi:10.1016/S0040-6090(98)01174-2

${ }^{3}$ C. C. Kuo, P. J. Huang, Rapid surface roughness measurements of silicone thin films with different thicknesses, Optik - International Journal for Light and Electron Optics, 123 (2012) 19, 1755-1760, doi:10.1016/j.ijleo.2011.11.048

${ }^{4}$ C. C. Kuo, Effects of angle of probe laser and pinhole diameter on the time-resolved optical inspection system, Optik - International Journal for Light and Electron Optics, 122 (2011) 20, 1799-1803, doi:10.1016/j.ijleo.2010.09.045

${ }^{5}$ C. C. Kuo, P. J. Huang, A low-cost and reliable optical inspection system for rapid surface roughness measurements of polycrystalline thin films, Materialwissenschaft und Werkstofftechnik, 43 (2012) 10, 878-885, doi:10.1002/mawe.201200876

${ }^{6}$ C. C. Kuo, C. S. Chao, Rapid optical measurement of surface roughness of polycrystalline thin films, Optics and Lasers in Engineering, 48 (2010) 12, 1166-1169, doi:10.1016/j.optlaseng.2010.07.007

${ }^{7}$ C. C. Kuo, Characterization of in-situ time-resolved optical spectra during excimer laser crystallization, Journal of Russian Laser Research, 30 (2009) 1, 12-20, doi:10.1007/s10946-009-9057-2

${ }^{8}$ C. C. Kuo, Characterization of Polycrystalline Ge Thin Films Fabricated by Excimer Laser Crystallization, Journal of Russian Laser Research, 29 (2008) 2, 167-175, doi:10.1007/s10946-008-9008-3

${ }^{9}$ C. C. Kuo, Characterization of Polycrystalline Silicon Thin Films Fabricated by Excimer Laser Crystallization, Journal of Russian Laser Research, 28 (2007) 4, 383-392, doi:10.1007/s10946-007-0027-2

${ }^{10} \mathrm{C}$. C. Kuo, A novel optical diagnostic technique for analyzing the recrystallization characteristics of polycrystalline silicone thin films following frontside and backside excimer laser irradiation, Optics and Lasers in Engineering, 49 (2011) 11, 1281-1288, doi:10.1016/ j.optlaseng.2011.06.008

${ }^{11}$ C. C. Kuo, C. S. Chao, A simple and cost-effective system for measuring the recrystallization characterization of polycrystalline silicon following excimer laser crystallization, Lasers in Engineering, 21 (2011) 5-6, 353-364

${ }^{12}$ C. C. Kuo, Non-destructive measurements on recrystallization and grain size characterization of polycrystalline silicon, Journal of Russian Laser Research, 32 (2011) 2, 130-138, doi:10.1007/s10946011-9198-y

${ }^{13}$ C. C. Kuo, Dynamical resolidification behavior of silicon thin films during frontside and backside excimer laser annealing, Optics and Lasers in Engineering, 49 (2011) 7, 804-810, doi:10.1016/ j.optlaseng.2011.03.006

${ }^{14}$ C. C. Kuo, In situ time-resolved optical measurements of a-Si thin films during excimer laser crystallization, Optik - International Journal for Light and Electron Optics, 122 (2011) 8, 655-659, doi:10.1016/j.ijleo.2010.04.023

${ }^{15} \mathrm{C}$. C. Kuo, On-line determination of average grain size of polycrystalline silicon from melt duration of molten silicon, Journal of
Russian Laser Research, 32 (2011) 1, 12-18, doi:10.1007/s10946011-9185-3

${ }^{16}$ C. C. Kuo, A non-destructive optical diagnostic technique for measuring the grain size of polycrystalline silicon produced by excimer laser crystallization, Laser Physics, 20 (2010) 6, 1525-1531, doi:10.1134/S1054660X10110113

${ }^{17}$ C. C. Kuo, Phase Transformation Mechanism in Pulsed Excimer Laser Crystallization of Amorphous Silicon Thin Films, Lasers in Engineering, 19 (2010) 3-4, 225-238

${ }^{18}$ J. S. Im, H. J. Kim, M. O. Thompson, Phase transformation mechanisms involved in excimer laser crystallization of amorphous silicon films, Applied Physics Letters, 63 (1993) 14, 1969-1971, doi:10.1063/1.110617

${ }^{19}$ J. S. Im, H. J. Kim, On the super lateral growth phenomenon observed in excimer laser-induced crystallization of thin Si film, Applied Physics Letters, 64 (1994) 17, 2303-2305, doi:10.1063/ 1.111651

${ }^{20}$ T. Sameshima, H. Watakabe, N. Andoh, S. Higashi, Pulsed Laser Annealing of Thin Silicon Films, Japanese Journal of Applied Physics, 45 (2006), 2437-2440, doi:10.1143/JJAP.45.2437

${ }^{21}$ M. Tsubuku, K. S. Seol, I. H. Choi, Y. Ohki, Enhanced Crystallization of Strontium Bismuth Tantalate Thin Films by Irradiation of Elongated Pulses of KrF Excimer Laser, Japanese Journal of Applied Physics, 45 (2006), 1689-1693, doi:10.1143/JJAP.45.1689

${ }^{22}$ L. Mariucci, A. Pecora, G. Fortunato, C. Spinella, C. Bongiorno, Crystallization mechanisms in laser irradiated thin amorphous silicon films, Thin Solid Films, 427 (2003) 1-2, 91-95, doi:10.1016/S00406090(02)01254-3

${ }^{23}$ D. H. Choi, E. Sadayuki, O. Sugiura, M. Matsumura, Lateral Growth of Poly-Si Film by Excimer Laser and Its Thin Film Transistor Application, Japanese Journal of Applied Physics, 33 (1994), 70-74, doi:10.1143/JJAP.33.70

${ }^{24}$ A. Rawlinson, C. Elcock, A. Cheung, A. Al-Buhairi, S. Khanna, T. F. Walsh, R. P. Ellwood, An in-vitro and in-vivo methodology study of alveolar bone measurement using extra-oral radiographic alignment apparatus, Image Pro-Plus ${ }^{\circledR}$ software and a subtraction programme, Journal of Dentistry, 33 (2005) 9, 781-788, doi:10.1016/j.jdent.2005. 01.013

${ }^{25}$ R. J. Blatt, A. N. Clark, J. Courtney, C. Tully, A. L. Tucker, Automated quantitative analysis of angiogenesis in the rat aorta model using Image-Pro Plus 4.1, Computer Methods and Programs in Biomedicine, 75 (2004) 1, 75-79, doi:10.1016/j.cmpb.2003.11.001

${ }^{26}$ C. C. Kuo, Solidification velocity in liquid silicon during excimer laser crystallization, Applied Physics A: Materials Science and Processing, 95 (2009) 2, 573-578, doi:10.1007/s00339-008-4953-9

${ }^{27}$ B. Rezek, C. E. Nebel, M. Stutzmann, Polycrystalline Silicon Thin Films Produced by Interference Laser Crystallization of Amorphous Silicon, Japanese Journal of Applied Physics, 38 (1999), L1083-L1084, doi:10.1143/JJAP.38.L1083

${ }^{28}$ G. Fortunato, L. Mariucci, R. Carluccio, A. Pecora, V. Foglietti, Excimer laser crystallization techniques for polysilicon TFTs, Applied Surface Science, 154-155 (2000), 95-104, doi:10.1016/ S0169-4332(99)00475-4

${ }^{29}$ D. Bouhafs, M. Fathi, L. Guerbous, Photoluminescence activity of Yang and Secco etched multicrystalline silicon material, Applied Surface Science, 252 (2006) 23, 8337-8340, doi:10.1016/j.apsusc. 2005.11.046

${ }^{30}$ J. Mahlib, A. Abbadie, B. O. Kolbesen, A comparison of the etching behaviour of the FS Cr-free SOI with that of the Secco etching solution on silicon-on-insulator substrates, Materials Science and Engineering B, 159-160 (2009), 309-313, doi:10.1016/j.mseb.2008. 09.008

${ }^{31}$ J. Zhang, C. Liu, Q. Zhou, J. Wang, Q. Hao, H. Zhang, Y. Li, Evolution of flow pattern defects in boron-doped $\left(\begin{array}{lll}1 & 0 & 0\end{array}\right)$ Czochralski silicon crystals during secco etching procedure, Journal of Crystal Growth, 269 (2004) 2-4, 310-316, doi:10.1016/j.jcrysgro.2004.05. 095 